\title{
QUALITY AND STORAGE ABILITY OF FRESH-CUT PEPPER TREATED BY 1-METHYLCYCLOPROPENE
}

\author{
Maria GRZEGORZEWSKA*, Ewa BADEŁEK, Anna WRZODAK, \\ Karol FABISZEWSKI, Anna CIECIERSKA \\ Research Institute of Horticulture \\ Konstytucji 3 Maja 1/3, 96-100, Skierniewice, Poland
}

Received: January 2020; Accepted: April 2020

\begin{abstract}
The study was conducted to assess the effect of 1-methylcyclopropene (1-MCP) treatment on the storage ability of fresh-cut pepper fruit. The cut fruit of pepper 'Yecla F1' were treated immediately after cutting and 'Roberta $\mathrm{F}_{1}$ ' before cutting. The 1-MCP at the concentrations of $1.0 \mu 1 \cdot \mathrm{dm}^{-3}, 3.0 \mu 1 \cdot \mathrm{dm}^{-3}$, and $5.0 \mu \mathrm{l} \cdot \mathrm{dm}^{-3}$ was applied to gas-tight containers with fruit for 20 hours at $20^{\circ} \mathrm{C}$. Peppers were stored at two temperatures: $0^{\circ} \mathrm{C}$ and $5{ }^{\circ} \mathrm{C}$, for up to 8 days. The treatment applied immediately after cutting slowed down the softening of pepper a little when fruit was stored at $0{ }^{\circ} \mathrm{C}$, as well as during subsequent shelf life. The treatment applied before cutting did not reduce the softening, discoloration as well as rotting of pepper strips in cold conditions and shelf life. The sensory evaluation showed that 1-MCP treatment, applied before or after cutting, did not improve the quality of fresh-cut pepper during short term storage. The ethylene concentration after 4 days of cold storage was higher inside the bags with treated fresh-cut pepper, as compared to the bags with untreated samples. These results can give important direction for pepper fruit storage.
\end{abstract}

Key words: fresh-cut pepper, 1-MCP treatment, storage ability

\section{INTRODUCTION}

The main problem in the production of freshcut vegetables is their poor durability in the trade, during storage and shelf life. Damage of tissues at cutting is the reason of the increasing intensity of physiological, biochemical, and microbiological processes (Cantwell \& Suslow 2002; Soliva-Fortuny \& Martin-Belloso 2003; Rico et al. 2007; Toivonen \& Brummell 2008; Cantwell 2012). The important attributes of quality of pepper fruit are: color, texture, aroma, and taste, as well as nutritional value (Mencarelli \& Saltveit 1988, Rico at al. 2007, Beaulieu 2011). Ethylene is plant hormone, produced by fruits and vegetables, which stimulates ripening, influences an increasing intensity of respiration, thereby accelerates senescence and spoilage of products (Saltveit 1999).
Non-climacteric vegetables, including pepper, during storage at low temperature produce only small amounts of ethylene, that does not affect their durability significantly. There is a large discrepancy in the literature regarding ethylene production by pepper fruit. According to Barrera et al. (2005), the production is lower than $0.01 \mu \mathrm{l} \cdot \mathrm{kg}^{-1} \cdot \mathrm{h}^{-1}$, whereas Cantwell (2012) reports that it is $0.1-0.2 \mu \mathrm{l} \cdot \mathrm{kg}^{-1} \cdot \mathrm{h}^{-1}$ at temperature $10-20^{\circ} \mathrm{C}$. Villavicencio et al. (1999) revealed that the production of ethylene depends on the cultivar and degree of pepper fruit maturity and can range from 0.002 to $1.1 \mu \mathrm{l} \mathrm{kg}^{-1} \cdot \mathrm{h}^{-1}$. According to Weichmann (1987), after cutting, there is a rapid increase of ethylene production amounting to $5.0 \mu \mathrm{l} \cdot \mathrm{kg}^{-1} \cdot \mathrm{h}^{-1}$ at $27^{\circ} \mathrm{C}$. When the cut vegetables are stored in packages with partially or completely limited permeability, ethylene is accumulated and remains in the nearest surrounding of vegetables. 
The ethylene concentration in the atmosphere of the stored vegetables, even in small amount (several $\mathrm{ppm}$ ), contributes to the acceleration of senescence, thus shortening of the cold storage period, as well as the period of shelf life. According to Koukounaras et al. (2006) and Toivonen (2008), the non-climacteric vegetables, both whole and cut, are exposed to exogenous ethylene present in the market due to the fruits and vegetables (apples, bananas, tomatoes), which generated large amounts of this gas.

One of the methods that is used to postpone the ripening and senescence of some fruits and vegetables during the storage and shelf life is postharvest 1 -methylcyclopropene (1-MCP) treatment. In the process of fresh cut vegetables, the treatment of 1-MCP can be applied immediately after the harvest of vegetables intended to minimal processing, after a certain period of storage of intact vegetables or immediately before or after cutting. Deceleration of the physiological and biochemical changes is the result of irreversible 1-MCP binding to the ethylene receptors, which prevents ethylene production and perception (Blankenship \& Dole 2003, Alabboud et al. 2017). The reduction of ethylene synthesis after 1-MCP treatment occurred in apple (Pre-Aymard et al. 2003), pear (Trinchero et al. 2004), avocado (Hershkovitz et al. 2005), peach, plum, and tomato (Watkins 2006). To the contrary, Pelayo-Zaldivar et al. (2003) reported that bananas treated with $1000 \mathrm{nl} \mathrm{dm}{ }^{-3} 1-\mathrm{MCP}$ at $20{ }^{\circ} \mathrm{C}$ for 6 or $24 \mathrm{~h}$, were characterized by higher ethylene production and lower respiration rates, and delay in the change of skin color and firmness of the flesh. In the studies of Ella et al. (2003), Jiang et al. (2002), and VilasBoas and Kader (2006), 1-MCP contributed to the increase of ethylene production in parsley leaves, coriander, and sliced bananas. Numerous examples have been quoted in the available literature, confirming the positive effect of 1-MCP on the improvement of fruit and vegetable durability. According to Blankenship and Dole (2003), the effect of 1-MCP depends on the vegetable species. It was also pointed out that the final effect depends on several factors, such as: cultivar, storage conditions, storage period before cutting, maturity stage at harvest (Jaing \& Joice 2002; Watkins 2008; Hurr et al. 2005).
The majority of research with post-harvest treatment of 1-MCP were carried out on whole and sliced climacteric fruits and vegetables. In the studies of Calderon-Lopez et al. (2005) and Rupasinghe et al. (2005), it was found that the positive effect on longer maintaining firmness and color of whole apples, depends on the cultivar as well as the storage period. Calderon-Lopez et al. (2005) reported that slices prepared from the fruits of cultivars, which positively responded to $1-\mathrm{MCP}$, had lower ethylene production rates and were firmer than those from the untreated fruits. However, slices prepared from untreated and 1-MCP-treated fruits deteriorated at similar rates. In the study by Bai et al. (2004), in which the treatment was carried out immediately prior to slicing, the improvement of firmness and taste was obtained for 'Gala', whereas treatment of the 'Pacific Rose' only inhibited discoloration (Petera et al. 2003). Tomatoes treated with 1-MCP prior to slicing did not show any improvement of quality. However, tomatoes treated after slicing with concentration $1 \mu \mathrm{l} \cdot \mathrm{dm}^{-3}$, had better firmness and less cellular juice leakage during shelf life period than the not treated samples (Jeong et al. 2004).

According to Saltveit (2004), 1-MCP blocked the ethylene induction and reduced the accumulation of polyphenols, which leads to delay the cut leaves' discolorations. 1-MCP treatment significantly protected Chinese mustard, choy sum, garland chrysanthemum, and tatsoi against yellowing and shelf life shortening in the presence of $1 \mu 1 \cdot \mathrm{dm}^{-3}$ ethylene (Able et al. 2003). Based on these findings, the authors argued that 1-MCP may have a good effect on minimally processed leafy Asian vegetables in storage or retail with plant products producing ethylene. Post-harvest application of 1-MCP $\left(1.0 \mu \mathrm{l} \cdot \mathrm{dm}^{-3}\right)$ clearly had an influence on the delay in the senescence as well as the maintenance of better quality of whole pepper fruit harvested in the "mature green" phase and then stored at 10 and $20^{\circ} \mathrm{C}$ (Shifeng et al. 2012). Li et al. (2011) reported that 1-MCP treatment and modified atmosphere packaging (MAP) reduce the activities of peroxidase, catalase superoxidase dismutase, but the pictures from atomic force microscope showed, that the surface of treated peppers are smoother than the control fruit. 
Also, 1-MCP reduced chilling injury symptoms during storage for 30 days at $5{ }^{\circ} \mathrm{C}$, which correlated with the decreasing of electrolyte leakage. Searching for a new method affecting the delay of softening and changing the taste and smell of minimally processed vegetables, it was decided to check the effect of 1-MCP on the storability and shelf life ability of fresh-cut pepper.

\section{MATERIALS AND METHODS}

The study with fresh-cut sweet pepper, treated with 1-MCP was carried out in 2013-2016. In 2013 and 2014, the pepper 'Yecla $F_{1}$ ' was purchased in the wholesale of the Papryka Polska, Producers Group. Immediately after bringing the pepper to the storage laboratory, the fruits were washed, cut into strips about $0.8 \mathrm{~cm}$ width and treated with $1-\mathrm{MCP}$ with the following concentrations: $1.0 \mu 1 \cdot \mathrm{dm}^{-3}$, $3.0 \mu \mathrm{l} \cdot \mathrm{dm}^{-3}$, and $5.0 \mu \mathrm{l} \cdot \mathrm{dm}^{-3}$. The control was pepper not treated with 1-MCP. The treatment was carried out inside gas-tight containers for 20 hours at $20^{\circ} \mathrm{C}$. The study used SmartFresh TM 0.14, obtained from AgroFresh Poland. In the subsequent years 20152016, the research was carried out with the pepper 'Roberta $F_{1}$ ', produced in the experimental field of Research Institute of Horticulture. In this experiment, the intact fruits were treated with 1-MCP immediately after washing and drying according to the protocol from the first experiment. Immediately after the treatment, the peppers were cut into strips. The fruit of both cultivars have cylindrical shape, red color, and thick flesh. 'Yecla $F_{1}$ ' is intended to under roof cultivation but 'Roberta $F_{1}$ ' to cultivation in open field. The storage experiments were set up in four replications of $200 \mathrm{~g}$ each. Each sample was packed in a perforated low density polyethylene (LDPE) bag of size $15 \times 20 \mathrm{~cm}$ with 10 holes $ø 0.4 \mathrm{~mm}$. The thickness of the film was $0.03 \mathrm{~mm}$. The volume of one bag was $885 \mathrm{ml}$, but one portion of fresh-cut pepper occupied $200 \mathrm{ml}$. Peppers were stored at two temperatures: $0{ }^{\circ} \mathrm{C}$ and $5{ }^{\circ} \mathrm{C}$ for up to 8 days. Additionally, 2 samples from each combination were prepared for sensory analysis and 2 samples for measurements of ethylene and carbon dioxide emissions. For sensory examination also, whole fruits stored at $8{ }^{\circ} \mathrm{C}$ were taken.
The samples with fresh-cut pepper were packed for the gases' content measurements into LDPE tightly closed bags without perforation. The sensory evaluation as well as gas measurement were made after 4 days of cold storage. The sensory evaluation was performed using Quantitative Descriptive Analysis method (QDA). Ethylene concentration inside the bags with cut pepper was measured using gas chromatograph Hewlett Packard 5890, but $\mathrm{CO}_{2}$ equipped with analyzer $\mathrm{CO}_{2}-\mathrm{ADC}-225-\mathrm{MK} 3$ (The Analytical Development CO LTD Hoddesdon, England). Every two days during storage, the samples were subjected to visual observation, and the following features were evaluated: softening, discoloration, rotting, chilling injury symptoms, and total quality, using the scale described in Table 1.

The results were analyzed statistically using two-factor analysis of variance, treating the storage temperature and 1-MCP concentration as variables in the model. The obtained averages were compared using the Tukey's test at $p=0.05$. The calculations were done independently for each storage time in the statistical package STATISTICA 13 (Dell 2016).

\section{RESULTS}

Fresh cut pepper 'Yecla $\mathrm{F}_{1}$ ' maintained very good quality during 4-day storage at both temperatures, $0{ }^{\circ} \mathrm{C}$ and $5{ }^{\circ} \mathrm{C}$. According to the evaluating scale, total quality assessment ranged from 8.0 to 9.0 after 4 days (data not shown) and from 6.3 to 7.5 after 6 days (Table 1). No visible softening, discoloration, and rotting after 4 days was recorded. The storage prolonged to 6 days revealed that the softening and the quality of pepper strips dropped to good under $0{ }^{\circ} \mathrm{C}$ and to below good under $5{ }^{\circ} \mathrm{C}$ (Table 1). It was a little impact of 1-MCP treatment on fresh-cut pepper quality during the storage at $0{ }^{\circ} \mathrm{C}$. The biggest softening was found for not treated pepper and it was the reason of the biggest quality degradation of this object. There was no discoloration of pepper neither treated nor untreated, and only in objects treated with 1-MCP at the concentration $1.0 \mu \mathrm{l} \cdot \mathrm{dm}^{-3}$, the very beginning of rotting was observed. After 6-day storage at $5{ }^{\circ} \mathrm{C}$, the softening of pepper strips was greater than at $0{ }^{\circ} \mathrm{C}$, but discoloration and rotting were not observed. 
No significant differences were found in the total quality for treated and untreated fresh-cut pepper stored at $5{ }^{\circ} \mathrm{C}$ (Table 1$)$.

If the fresh-cut pepper was moved, after cold storage, to $18-20^{\circ} \mathrm{C}$, the quality degradation accelerated. The samples, showing very good quality after 4 days at $0{ }^{\circ} \mathrm{C}$ and $5{ }^{\circ} \mathrm{C}$, after another day in shelf life, showed signs of senescence and decreasing of quality. It was particularly evident on the pepper stored at $5{ }^{\circ} \mathrm{C}$. After 1 day of shelf life, this pepper was commercially not useful because of softening, discoloration, and rotting. (Table 2). In both years, no symptoms of chilling injury on fresh-cut pepper was observed during cold storage at 0 and $5{ }^{\circ} \mathrm{C}$, as well as during the subsequent shelf life.

The fresh-cut pepper 'Roberta $F_{1}$ ', treated with 1-MCP immediately before cutting, showed big discrepancy in storage ability between the years of the study. In 2015, the pepper remained very good quality for 6 and 8 days at $0{ }^{\circ} \mathrm{C}$ and $5{ }^{\circ} \mathrm{C}$ (Table 3). In 2016 , the very good quality of the pepper remained only for 4 days of storage (data not shown), but after 6 and 8 days, the quality dropped to 6 and 4.5, respectively; whereas in 2015, this parameter amounted to 8 . By prolonging the storage time, the softening of pepper strips was recorded after storage at both temperatures. During the time of experiment, no discoloration and rotting decay appeared on the pepper at both temperatures $\left(0^{\circ} \mathrm{C}\right.$ and $5{ }^{\circ} \mathrm{C}$; data not shown). The assessment of the quality of 1MCP treated pepper 'Roberta $F_{1}$ ' showed that there were no differences in the marketable value among the strips from the control object and objects treated with 1-MCP of different concentrations (data not showed). During the storage time, the softening and total quality changed in the same rate for all experimental combination at the same temperature.

After four days at cold storage and another day of shelf life, much better quality maintained pepper 'Roberta $\mathrm{F}_{1}$ ' in 2015 than 2016. In both years, discoloration and rotting were not recorded, but softening was greater and total quality lower in 2016 (Table 4). After shelf life, the influence of 1-MCP treatment on cut-pepper quality in both 2015 and 2016 was not recorded (data not showed). In 2015, a little better hardness and total quality maintained pepper stored at $0{ }^{\circ} \mathrm{C}$ than at $5{ }^{\circ} \mathrm{C}$. In the next year, there were no differences in the quality of pepper depending on the temperature of cold storage (Table 4). Similar to the pepper treated after cutting, there were no chilling injury on the pepper in 2015-2016.

The sensory analysis confirmed that 1-MCP treatment did not influence significantly the quality of fresh cut pepper during short term storage. The pepper treated before or after cutting and storing for 4 days at $0{ }^{\circ} \mathrm{C}$ were characterized by very little foreign taste and smell (below 0.7 in 0-10 scale; Fig. $1 \mathrm{~A} \& 2 \mathrm{~A})$. After storage at higher temperature $\left(5{ }^{\circ} \mathrm{C}\right)$, the foreign taste and smell were more noticeable than after storage at $0{ }^{\circ} \mathrm{C}$ (Fig. $1 \mathrm{~B} \& 2 \mathrm{~B}$ ). Comparing the sensory quality of fresh-cut pepper to intact pepper, generally at both temperatures, a little better results were obtained for intact pepper. In the case of pepper treated with $1.0 \mu \mathrm{l} \cdot \mathrm{dm}^{-3}$ of $1-\mathrm{MCP}$ after cutting and storing for 4 days at $5{ }^{\circ} \mathrm{C}$, the characteristic pepper smell was weaker than of pepper from other experimental objects (Fig. $1 \& 2$ ).

The results of ethylene content in tightly closed bags, in which fresh-cut pepper was stored for 4 days, indicated that higher amounts of this gas was produced by the treated than the untreated samples of 'Yecla $F_{1}$ '. In 'Roberta $F_{1}$ ' samples, this dependence was not very clear. Generally, more ethylene was found in bags with peppers stored at $0{ }^{\circ} \mathrm{C}$ than at $5{ }^{\circ} \mathrm{C}$. Only in the case of pepper 'Roberta $\mathrm{F}_{1}$ ' treated by $5.0 \mu \mathrm{l} \cdot \mathrm{dm}^{-3}$ of $1-\mathrm{MCP}$, more ethylene was produced at $5{ }^{\circ} \mathrm{C}$ than $0{ }^{\circ} \mathrm{C}$, but the difference was insignificant (Table 5).

The carbon dioxide production during storage for 4 days at $0{ }^{\circ} \mathrm{C}$ was not different between pepper samples treated and untreated with 1-MCP. At $5^{\circ} \mathrm{C}$, significantly more $\mathrm{CO}_{2}$ was found in the bags with samples treated with $5.0 \mu 1 \cdot \mathrm{dm}^{-3}$ than for untreated and treated with lower doses of 1-MCP. At temperature $5{ }^{\circ} \mathrm{C}$, treatment with $5.0 \mu \mathrm{l} \cdot \mathrm{dm}^{-3}$ of $1-\mathrm{MCP}$ stimulated $\mathrm{CO}_{2}$ production. The higher concentration of this gas was inside the bags with fresh-cut pepper stored at $5{ }^{\circ} \mathrm{C}$ than at $0{ }^{\circ} \mathrm{C}$ (Table 6). 
Table 1. The influence of 1-MCP treatment after fruit cutting on quality of cut pepper 'Yecla $\mathrm{F}_{1}$ ' after 6 days of storage (means of 2013 and 2014)

\begin{tabular}{cccccc}
\hline \multirow{2}{*}{$\begin{array}{c}\text { Storage } \\
\text { temperature }\end{array}\left({ }^{\circ} \mathrm{C}\right)$} & $\begin{array}{c}\text { Concentration } \\
\text { of 1-MCP } \\
\left(\mu \mathrm{l} \cdot \mathrm{dm}^{-3}\right)\end{array}$ & softening & discoloration & rotting & total quality \\
\cline { 4 - 6 } & 0.0 & $1.8 \pm 0.26 \mathrm{~b}$ & $1.0 \pm 0.00$ & $1.0 \pm 0.00 \mathrm{a}$ & $7.0 \pm 0.00 \mathrm{~b}$ \\
& 1.0 & $1.3 \pm 0.27 \mathrm{a}$ & $1.0 \pm 0.00$ & $1.1 \pm 0.09 \mathrm{~b}$ & $7.3 \pm 0.46 \mathrm{ab}$ \\
0 & 3.0 & $1.3 \pm 0.27 \mathrm{a}$ & $1.0 \pm 0.00$ & $1.0 \pm 0.00 \mathrm{a}$ & $7.5 \pm 0.53 \mathrm{a}$ \\
& 5.0 & $1.3 \pm 0.27 \mathrm{a}$ & $1.0 \pm 0.00$ & $1.0 \pm 0.00 \mathrm{a}$ & $7.5 \pm 0.53 \mathrm{a}$ \\
\hline & 0.0 & $2.4 \pm 0.44 \mathrm{e}$ & $1.0 \pm 0.00$ & $1.0 \pm 0.00$ & $6.3 \pm 0.87 \mathrm{c}$ \\
5 & 1.0 & $2.3 \pm 0.27 \mathrm{~d}$ & $1.0 \pm 0.00$ & $1.0 \pm 0.00$ & $6.5 \pm 0.53 \mathrm{c}$ \\
& 3.0 & $2.4 \pm 0.50 \mathrm{e}$ & $1.0 \pm 0.00$ & $1.0 \pm 0.00$ & $6.3 \pm 0.75 \mathrm{c}$ \\
& 5.0 & $2.1 \pm 0.69 \mathrm{c}$ & $1.0 \pm 0.00$ & $1.0 \pm 0.00$ & $6.6 \pm 1.13 \mathrm{c}$ \\
\hline
\end{tabular}

Means in columns signed with the same letter do not differ significantly at $\mathrm{p}=0.05$, according to Tukey's test. Quality evaluating scales: softening: 1 - lack, 3 - light, 5 - medium (clearly perceptible), 7 - strong (soft stripes), 9 - very strong (completely soft stripes); discoloration: 1 - none, 3 - light, 5 - medium (clearly visible), 7 - strong, 9 - very strong (brown); rotting: 1 - no, 3 - light, 5 - medium (clearly visible), 7 - strong, 9 - very strong (100\% rotten; overall quality: 9 - excellent (as after cutting), 7 - good (slight defects, slightly lowering the quality), 5 - sufficient (light and medium defects - lower limit of marketability), 3 - fair (limit of usability), 1 - poor (inedible)

Table 2. The influence of $1-\mathrm{MCP}$ treatment after cutting on the quality of cut pepper 'Yecla $\mathrm{F}_{1}$ ' after 4 days of cold storage and one day at $18-20{ }^{\circ} \mathrm{C}$ (means of 2013 and 2014)

\begin{tabular}{|c|c|c|c|c|c|}
\hline \multirow{2}{*}{$\begin{array}{c}\text { Storage } \\
\text { temperature } \\
\left({ }^{\circ} \mathrm{C}\right)\end{array}$} & \multirow{2}{*}{$\begin{array}{c}\text { Concentration } \\
\text { of } 1-\mathrm{MCP} \\
\left(\mu \mathrm{l} \cdot \mathrm{dm}^{-3}\right)\end{array}$} & \multicolumn{4}{|c|}{ Quality of cut pepper } \\
\hline & & softening & discoloration & rotting & total quality \\
\hline \multirow{4}{*}{0} & 0.0 & $1.5 \pm 0.58$ & $1.0 \pm 0.00$ & $1.1 \pm 0.12$ & $6.8 \pm 0.29 \mathrm{~b}$ \\
\hline & 1.0 & $1.4 \pm 0.58$ & $1.0 \pm 0.00$ & $1.1 \pm 0.12$ & $7.0 \pm 0.00 \mathrm{ab}$ \\
\hline & 3.0 & $1.3 \pm 0.28$ & $1.0 \pm 0.00$ & $1.1 \pm 0.12$ & $7.3 \pm 0.29 \mathrm{a}$ \\
\hline & 5.0 & $1.3 \pm 0.58$ & $1.0 \pm 0.00$ & $1.1 \pm 0.12$ & $7.3 \pm 0.29 \mathrm{a}$ \\
\hline \multirow{4}{*}{5} & 0.0 & $2.0 \pm 1.15$ & $1.3 \pm 0.58$ & $1.5 \pm 0.58$ & $4.0 \pm 1.78 \mathrm{c}$ \\
\hline & 1.0 & $2.0 \pm 1.15$ & $1.5 \pm 0.58$ & $1.5 \pm 0.58$ & $3.8 \pm 1.44 \mathrm{c}$ \\
\hline & 3.0 & $1.5 \pm 0.58$ & $1.3 \pm 0.28$ & $1.5 \pm 0.58$ & $4.0 \pm 1.15 \mathrm{c}$ \\
\hline & 5.0 & $2.0 \pm 1.15$ & $1.5 \pm 0.58$ & $1.5 \pm 0.58$ & $3.8 \pm 1.44 \mathrm{c}$ \\
\hline
\end{tabular}

Means signed with different letters differ significantly at $\mathrm{p}=0.05$. Quality evaluating scales: such as under Table 1

Table 3. The quality of fresh-cut pepper 'Roberta $\mathrm{F}_{1}$ ' during the cold storage

\begin{tabular}{|c|c|c|c|c|}
\hline \multirow{3}{*}{$\begin{array}{c}\text { Storage } \\
\text { temperature } \\
\left({ }^{\circ} \mathrm{C}\right)\end{array}$} & \multicolumn{4}{|c|}{ Storage time (days) } \\
\hline & \multicolumn{2}{|c|}{6} & \multicolumn{2}{|c|}{8} \\
\hline & softening & total quality & softening & total quality \\
\hline \multicolumn{5}{|c|}{2015} \\
\hline 0 & $1.0 \pm 0.00$ & $8.5 \pm 0.00$ & $1.1 \pm 0.00$ & $8.0 \pm 0.00$ \\
\hline 5 & $1.1 \pm 0.00$ & $8.0 \pm 0.00$ & $1.3 \pm 0.00$ & $7.5 \pm 0.00$ \\
\hline \multicolumn{5}{|c|}{2016} \\
\hline 0 & $2.5 \pm 0.00$ & $6.0 \pm 0.00$ & $4.5 \pm 0.00$ & $4.5 \pm 0.00$ \\
\hline 5 & $2.5 \pm 0.00$ & $6.0 \pm 0.00$ & $4.5 \pm 0.00$ & $4.5 \pm 0.00$ \\
\hline
\end{tabular}

Data for all experimental objects within the same temperature and the same year are the same. Quality assessment scales: such as under Table 1 
Table 4. The quality of fresh-cut pepper 'Roberta $\mathrm{F}_{1}$ ' after 4 days of cold storage and one day at shelf life at $18-20{ }^{\circ} \mathrm{C}$ (means of 2015-2016)

\begin{tabular}{|c|c|c|c|c|}
\hline \multirow{2}{*}{$\begin{array}{c}\text { Storage } \\
\text { temperature } \\
\left({ }^{\circ} \mathrm{C}\right)\end{array}$} & \multicolumn{4}{|c|}{ Quality of cut pepper } \\
\hline & softening & discoloration & rotting & total quality \\
\hline \multicolumn{5}{|c|}{2015} \\
\hline 0 & $1.1 \pm 0.00$ & $1.0 \pm 0.00$ & $1.0 \pm 0.00$ & $8.0 \pm 0.00$ \\
\hline 5 & $1.5 \pm 0.00$ & $1.0 \pm 0.00$ & $1.0 \pm 0.00$ & $7.5 \pm 0.00$ \\
\hline \multicolumn{5}{|c|}{2016} \\
\hline 0 & $2.5 \pm 0.00$ & $1.0 \pm 0.00$ & $1.0 \pm 0.00$ & $6.5 \pm 0.00$ \\
\hline 5 & $2.5 \pm 0.00$ & $1.0 \pm 0.00$ & $1.0 \pm 0.00$ & $6.5 \pm 0.00$ \\
\hline
\end{tabular}

Data for all experimental objects within the same temperature and the same year are the same. Quality assessment scales: such as under Table 1
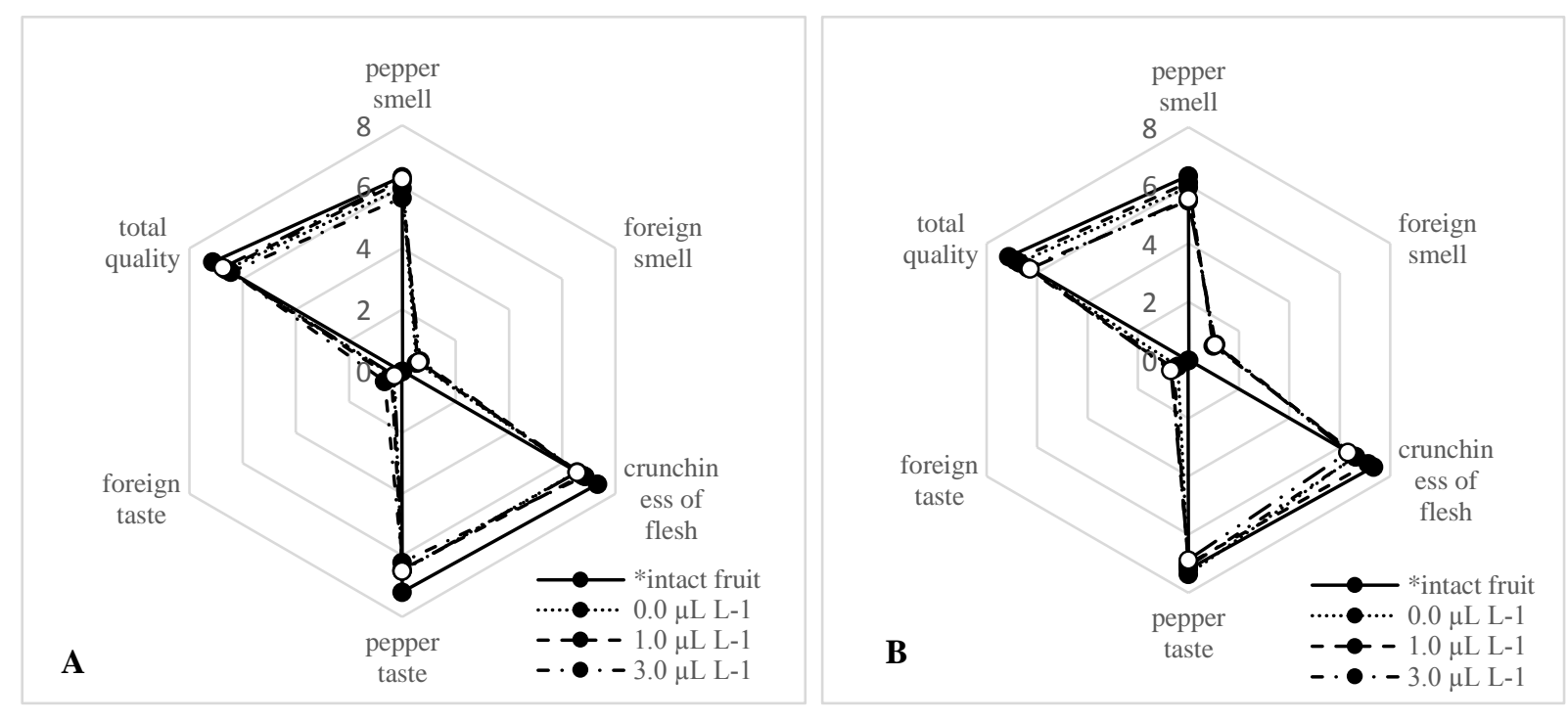

* not treated with 1 -MCP and stored at $8{ }^{\circ} \mathrm{C}$ as intact fruit evaluation scale: 0 - minimally value, 10 - maximally value

Fig. 1. Sensory quality of fresh cut pepper 'Yecla $\mathrm{F}_{1}$ ' treated by 1-MCP before cutting (A - after 4 days at $0^{\circ} \mathrm{C}, \mathrm{B}$ - after 4 days at $5^{\circ} \mathrm{C}$, means from 2013 and 2014)
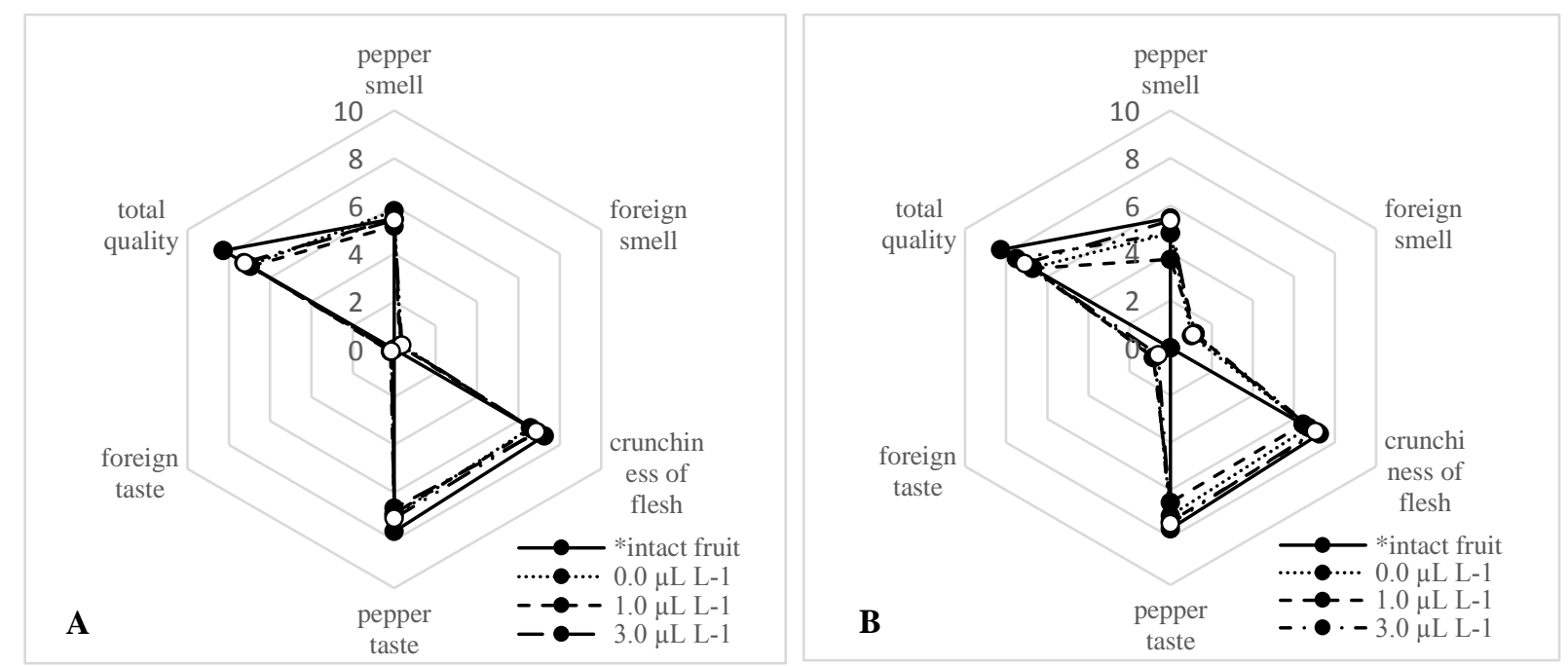

Note: See Fig. 1

Fig. 2. Sensory quality of fresh cut pepper 'Roberta $\mathrm{F}_{1}$ ' treated by $1-\mathrm{MCP}$ immediately after cutting (A - after 4 days at $0{ }^{\circ} \mathrm{C}, \mathrm{B}-$ after 4 days at $5{ }^{\circ} \mathrm{C}$, means from 2013 and 2014) 
Table 5. The ethylene concentration $\left(\mu \mathrm{l} \cdot \mathrm{dm}^{-3}\right)$ in packs with sliced pepper treated with 1-MCP (4 days of storage)

\begin{tabular}{|c|c|c|c|c|}
\hline \multirow{2}{*}{$\begin{array}{l}\text { Storage temperature } \\
\qquad\left({ }^{\circ} \mathrm{C}\right)\end{array}$} & \multicolumn{4}{|c|}{ 1-MCP concentration $\left(\mu \mathrm{l} \cdot \mathrm{dm}^{-3}\right)$} \\
\hline & $0.0 \mu \mathrm{l} \cdot \mathrm{dm}^{-3}$ & $1.0 \mu \mathrm{l} \cdot \mathrm{dm}^{-3}$ & $3.0 \mu \mathrm{l} \cdot \mathrm{dm}^{-3}$ & $5,0 \mu \mathrm{l} \cdot \mathrm{dm}^{-3}$ \\
\hline \multicolumn{5}{|c|}{ Means from 2013 and 2014 - 'Yecla F ' treated after cutting } \\
\hline 0 & $0.85 \pm 0.37 \mathrm{ab}$ & $2.60 \pm 1.88 \mathrm{~d}$ & $2.57 \pm 1.33 \mathrm{~d}$ & $2.90 \pm 1.78 \mathrm{~d}$ \\
\hline 5 & $0.40 \pm 0.24 \mathrm{a}$ & $1.18 \pm 0.88 \mathrm{bc}$ & $1.85 \pm 0.73 \mathrm{c}$ & $1.65 \pm 0.88 \mathrm{c}$ \\
\hline \multicolumn{5}{|c|}{ Means from 2015 and 2016 - 'Roberta $F_{1}$ ' treated before cutting } \\
\hline 0 & $0.55 \pm 0.12 \mathrm{ab}$ & $1.32 \pm 0.48 \mathrm{c}$ & $0.67 \pm 0.30 \mathrm{ab}$ & $0.47 \pm 0.16 \mathrm{ab}$ \\
\hline 5 & $0.26 \pm 0.15 \mathrm{a}$ & $0.68 \pm 0.29 \mathrm{ab}$ & $0.56 \pm 0.19 \mathrm{ab}$ & $0.71 \pm 0.41 \mathrm{~b}$ \\
\hline
\end{tabular}

The mean for each cultivar signed with the same letter do not differ significantly at $p=0.05$ according to Tukey's test

Table 6. The carbon dioxide concentration (\%) in packs with sliced pepper 'Roberta $\mathrm{F}_{1}$ ' treated with 1-MCP after cutting, after 4 days of storage (means of 2015-2016)

\begin{tabular}{ccccc}
\hline \multirow{2}{*}{$\begin{array}{c}\text { Storage temperature } \\
\left({ }^{\circ} \mathrm{C}\right)\end{array}$} & $0.0 \mu \mathrm{l} \cdot \mathrm{dm}^{-3}$ & $1.0 \mu \mathrm{l} \cdot \mathrm{dm}^{-3}$ & $3.0 \mu \mathrm{l} \cdot \mathrm{dm}^{-3}$ & $5.0 \mu \mathrm{l} \cdot \mathrm{dm}^{-3}$ \\
\cline { 2 - 4 } 0 & $1.99 \pm 0.19 \mathrm{ab}$ & $1.98 \pm 0.09 \mathrm{ab}$ & $1.84 \pm 0.21 \mathrm{ab}$ & $1.68 \pm 0.41 \mathrm{a}$ \\
5 & $2.03 \pm 0.76 \mathrm{ab}$ & $2.19 \pm 0.09 \mathrm{ab}$ & $2.37 \pm 0.21 \mathrm{~b}$ & $2.91 \pm 0.31 \mathrm{c}$ \\
\hline
\end{tabular}

The mean signed with the same letter do not differ significantly at $p=0.05$ according to Tukey's test

\section{DISCUSSION}

Cut pepper fruit, like other minimally processed vegetables, are in a group of easy perishable horticulture commodities and can be stored only for a very short time. Many authors discussed this problem previously. For example, fresh-cut lettuce can be stored only for 2-5 days depending on the type of packaging (Kang et al. 2007), freshcut tomato even for 10 days at $2{ }^{\circ} \mathrm{C}$ (Artes et al. 1999). According to Cantwell (2012), the potential storage life for fresh-cut pepper is 4-9 days. The main reason of pepper strips' storage limitation is softening, which also happened to other fresh cut vegetables (Mencarelli \& Saltveit 1988; Rico et al. 2007). Alabboud et al. (2017) reported about better firmness of treated tomatoes' storage at $10{ }^{\circ} \mathrm{C}$ after $0.5 \mu \mathrm{l} \cdot \mathrm{dm}^{-3} 1-\mathrm{MCP}$ treatment in comparison to the not treated fruit. In the Hurr et al. (2005) studies, 1-MCP delayed or slowed the softening of tomato fruit of every maturity class.
Similarly, some apple cultivars treated by $1-\mathrm{MCP}$ softened only a little during the shelf life period (Watkins et al. 2000).The temperature had an impact on the storage ability of fresh-cut pepper and $0{ }^{\circ} \mathrm{C}$ that turned up to be better than $5{ }^{\circ} \mathrm{C}$. Cantwell and Suslow (2002) and Cantwell (2012) recommend temperature $1-2{ }^{\circ} \mathrm{C}$ for fresh-cut pepper. Although intact pepper is sensitive to chilling injury, there was no evidence of these damages on freshcut pepper during storage and shelf life. This may arise from the fact that in so perishable product, the sings of chilling injury do not become visible before spoilage and loss of suitability for consumption. Cantwell and Suslow (2002) suggested that low temperature retards the rate of deterioration of the fresh-cut products more than induces chilling injury. Additionally, Li et al. (2011) reported that 1 -MCP reduced chilling injury symptoms on intake fruit of sweet pepper. It is possible that 1-MCP also decreases chilling injury on fresh-cut pepper. The discoloration was not a problem during the storage of red color pepper in our experiments. 
It is in contrast to Cantwell and Suslow (2002), which found texture loss and browning during storage at $0-5{ }^{\circ} \mathrm{C}$ sliced and diced pepper, while in the Sangsuwan et al. (2008) study, the color of fresh-cut cantaloupe also remained unchanged during the 12 days of storage period. In our study, the 1-MCP with concentration 3.0 and $5.0 \mu \mathrm{l} \cdot \mathrm{dm}^{-3}$ increased slightly the quality of fresh-cut pepper treated directly after cutting. Better quality results, mainly because of maintaining better hardness during storage, were obtained after storage at $0{ }^{\circ} \mathrm{C}$, than at $5{ }^{\circ} \mathrm{C}$. After one day of shelf life also, the pepper previously stored at $0{ }^{\circ} \mathrm{C}$ that at $5{ }^{\circ} \mathrm{C}$ showed better quality. 1-MCP treatment applied before the cutting of pepper 'Roberta $F_{1}$ ' did not affect the quality during short term cold storage and subsequent shelf life of fresh-cut fruit. Toivonen (2008) also found better firmness of tomato slices treated with 1-MCP in the concentration $1.0 \mu \mathrm{l} \cdot \mathrm{dm}^{-3}$, while no benefit was obtained when 1-MCP treatment was carried out on intact tomato fruit before slicing. Similarly, banana did not respond when it was given on whole fruit, but the post-cutting application reduced softening of slices (Vilas-Boas \& Kader 2006). Unexpectedly, in our study, after 1-MCP treatment, there was an increase of ethylene production, especially when pepper was treated after cutting. Most reports indicate the decrease of ethylene production after 1-MCP treatment, but there are some, in which the elevation of ethylene biosynthesis took place. Much more ethylene, after 1-MCP application, was produced in parsley leaves (Ella et al. 2003), coriander (Jiang et al. 2002), and sliced banana (Vilas-Boas \& Kader 2006). Vilas-Boas and Kader (2006) reported [after Golding et al. (1999)] that 1-MCP may block the feedback regulation of ethylene production and the translation of 1-aminocyclopropane-1-carboxylate (ACC) synthase may be enhanced, which can lead to magnifying the ethylene production. However, Lee et al. (2010) proved that in pepper fruit, the ACC synthase and ACC oxidase does not occur, and others factors are responsible for ethylene induction. Another way of ethylene production can be lack of blocking the ethylene receptors by 1-MCP, but the stress brought by treatment can lead to the increase of ethylene synthesis. It is a surprise that the higher ethylene production was at $0{ }^{\circ} \mathrm{C}$ than at $5{ }^{\circ} \mathrm{C}$.
These results may indicate that the most stressful condition for pepper, as thermophilic vegetable, was at $0{ }^{\circ} \mathrm{C}$ than $5{ }^{\circ} \mathrm{C}$.

\section{CONCLUSION}

The results obtained do not allow for the unambiguous statement whether 1-MCP treatment in concentrations $1.0 \mu \mathrm{l} \cdot \mathrm{dm}^{-3}, 3.0 \mu \mathrm{l} \cdot \mathrm{dm}^{-3}$, and $5.0 \mu \mathrm{l} \cdot \mathrm{dm}^{-3}$ influences the storage ability and sensory quality of fresh cut pepper. The treatment performed immediately after cutting slows down only a little the softening of pepper strips, but treatment before cutting does not reduce the degradation process of pepper strips in cold condition and during 1-day shelf life. The effect of 1-MCP on ethylene production was opposite to the expected one, because instead of reducing, it enhanced the production of ethylene.

\section{Funding}

This research did not receive any specific grant from the funding agencies in the public, commercial, or non-profit sectors.

\section{Notes}

The authors declare no competing financial interest.

\section{Acknowledgments}

The authors would like to thank prof. Robert Maciorowski for his statistical expertise.

\section{REFERENCES}

Able A.J., Wong L.S., Prasad A., O'Hare T.J. 2003. The effect of 1-methylcyclopropene on the shelf life of minimally processed leafy Asian vegetables. Postharvest Biology and Technology 27: 157-161. DOI: 10.1016/s0925-5214(02)00093-5.

Alabboud M., Mohi Alden K., Alali F.A. 2017. Using 1-Methylcyclopropene (1-MCP) as an ethylene inhibitor in horticultural crops storage (a review). Sustainable Development, Strategies and Challenges With a focus on Agriculture, Natural Resources, Environment and Tourism. 7-9 March, Tabriz, Iran.

Artés F., Conesa M.A., Hernández S., Gil M.I. 1999. Keeping quality of fresh-cut tomato. Postharvest Biology and Technology 17: 153-162. DOI: 10.1016/s0925-5214(99)00044-7. 
Bai J., Baldwin E.A., Soliva Fortuny R.C., Mattheis J.P., Stanley R., Perera C., Brecht J.K. 2004. Effect of pre-treatment of intact 'Gala' apple with ethanol vapor, heat, or 1-methylcyclopropene on quality and shelf life of fresh-cut slices. Journal of the American Society for Horticultural Science 129: 583-593. DOI: 10.21273/jashs.129.4.0583.

Barrera J.A., Hernández M.S., Melgarejo L.M., Fernández-Trujillo J.P. 2005. Physiological changes in Amazonic hot pepper accessions during growth, ripening and storage. Acta Horticulturae 682: 2207 2214. DOI: 10.17660/actahortic.2005.682.301.

Beaulieu J.C. 2011. Factors Affecting Sensory Quality of Fresh-Cut Produce. In: Martín-Belloso O., SolivaFortuny R. (Eds.), Advances in Fresh-Cut Fruits and Vegetables Processing. CPS Press, pp. 115143. DOI: $10.1201 / \mathrm{b} 10263-6$.

Blankenship S.M., Dole J.M. 2003. 1-Methylcyclopropene: a review. Postharvest Biology and Technology 28: 1-25. DOI: 10.1016/S0925-5214(02)00246-6.

Calderon-Lopez B., Bartsch J.A., Lee C.Y., Watkins C.B. 2005. Cultivar effects on quality of fresh cut apple slices from 1-methylcyclopropene (1-MCP)-treated apple fruit. Journal of Food Science 70: 221-227. DOI: 10.1111/j.1365-2621.2005.tb07161.x.

Cantwell M., Suslow T. 2002. Fresh-cut fruits and vegetables: Aspects of physiology, preparation and handling that affect quality. Postharvest Technology Horticultural Products, publ. 3311, section 5g, 23 p. http://postharvest.ucdavis.edu

Cantwell M. 2012. Quality and Safety of Fresh-Cut Produce. Postharvest Technology Book. Postharvest Short Course, June 2012. http://ucce.ucdavis.edu/files/datastore/234-2226.pdf

Cao S., Yang Z., Zheng Y. 2012. Effect of 1-methylcyclopropene on senescence and quality maintenance of green bell pepper fruit during storage at $20^{\circ} \mathrm{C}$. Postharvest Biology and Technology 70: 1-6. DOI: 10.1016/j.postharvbio.2012.03.005.

Ella L., Zion A., Nehemia A., Amnon L. 2003. Effect of the ethylene action inhibitor 1-methylcyclopropene on parsley leaf senescence and ethylene biosynthesis. Postharvest Biology and Technology 30: 6774. DOI: 10.1016/s0925-5214(03)00080-2.

Golding J.B., Shearer D., McGlasson W.B., Wyllie S.G. 1999. Relationships between respiration, ethylene, and aroma production in ripening banana. Journal of Agricultural and Food Chemistry 47: 16461651. DOI: $10.1021 /$ jf980906c.
Hershkovitz V., Saguy S.I., Pesis E. 2005. Postharvest application of 1-MCP to improve the quality of various avocado cultivars. Postharvest Biology and Technology 37: 252-264. DOI: 10.1016/j.postharvbio.2005.05.003.

Hurr B.M., Huber D.J., Lee J.H. 2005. Differential responses in color changes and softening of 'Florida 47' tomato fruit treated at green and advanced ripening stages with the ethylene antagonist 1-methylcyclopropene. HortTechnology 15: $617-$ 622. DOI: 10.21273/horttech.15.3.0617.

Jeong J., Brecht J.K., Huber D.J., Sargent S.A. 2004. 1Methylcyclopropene (1-MCP) for maintaining texture quality of fresh-cut tomato. HortScience 39(6): 1359-1362. DOI: 10.21273/hortsci.39.6.1359.

Jiang Y., Joyce D.C. 2002. 1-Methylcyclopropene treatment effects on intact and fresh-cut apple. Journal of Horticultural Science and Biotechnology 77: 1921. DOI: $10.1080 / 14620316.2002 .11511450$.

Jiang W., Sheng Q., Zhou X.J., Zhang M.J., Liu X.J. 2002. Regulation of detached coriander leaf senescence by 1-methylcyclopropene and ethylene. Postharvest Biology and Technology 26: 339-345. DOI: 10.1016/s0925-5214(02)00068-6.

Kang S.C, Kim M.J., Choi U.K. 2007. Shelf-life extension of fresh-cut iceberg lettuce (Lactuca sativa L) by different antimicrobial films. Journal of Microbiology and Biotechnology 17(8): 1284-1290. https://pdfs.semanticscholar.org/2eef/7ca9c496f67b2cd4883f49c245 6677a1824d.pdf

Koukounaras A., Siomos A.S., Sfakiotakis E. 2006. 1Methylcyclopropene prevents ethylene induced yellowing of rocket leaves. Postharvest Biology and Technology 41: 109-111. DOI: 10.1016/j.postharvbio.2006.01.018.

Lee S., Chung E.J., Jung Y.H., Choi D. 2010. Non-climacteric fruit ripening in pepper: increased transcription of EIL-like genes normally regulated by ethylene. Functional and Integrative Genomics 10: 135-146. DOI: 10.1007/s10142-009-0136-9.

Li X., Yun J., Fan X., Xing Y., Tang Y. 2011. Effect of 1-methylcyclopropene and modified atmosphere packaging on chilling injury and antioxidative defensive mechanism of sweet pepper. African Journal of Biotechnology 10(34): 6581-6589. DOI: 10.5897/ajb10.2277.

Mencarelli F., Saltveit M.E. Jr. 1988. Ripening of maturegreen tomato fruit slices. Journal of the American Society for Horticultural Science 113: 742-745. 
Pelayo C., Vilas-Boas E.V. de B., Benichou M., Kader A.A. 2003. Variability in responses of partially ripe bananas to 1-methylcyclopropene. Postharvest $\mathrm{Bi}$ ology and Technology 28: 75-85. DOI: 10.1016/s0925-5214(02)00124-2.

Perera C.O., Balchin L., Baldwin E., Stanley R., Tian. M. 2003. Effect of 1-methylcyclopropene on the quality of fresh-cut apple slices. Journal of Food Science 68: 1910-1014. DOI: 10.1111/j.13652621.2003.tb06992.x.

Pre-Aymard C., Weksler A., Lurie S. 2003. Responses of 'Anna', a rapidly ripening summer apple, to 1methylcyclopropene. Postharvest Biology and Technology 27(2): 163-170. DOI: 10.1016/s09255214(02)00069-8.

Rico D., Martín-Diana A.B., Barat J.M., Barry-Ryan C. 2007. Extending and measuring the quality of fresh-cut fruit and vegetables: a review. Trends in Food Science and Technology 18(7): 373-386. DOI: 10.1016/j.tifs.2007.03.011.

Rupasinghe H.P.V., Murr D.P., DeEll J.R., Odumeru J. 2005. Influence of 1-methylcyclopropene and $\mathrm{Na}$ ture Seal on the quality of fresh-cut 'Empire' and 'Crispin' apples. Journal of Food Quality 28: 289307. DOI: 10.1111/j.1745-4557.2005.00035.x.

Saltveit M.E. 1999. Effect of ethylene on quality of fresh fruits and vegetables. Postharvest Biology and Technology 15: 279-292. DOI: 10.1016/s09255214(98)00091-X.

Saltveit M.E. 2004. Effect of 1-methylcyclopropene on phenylpropanoid metabolism, the accumulation of phenolic compounds, and browning of whole and fresh-cut 'iceberg' lettuce. Postharvest Biology and Technology 34: 75-80. DOI: 10.1016/j.postharvbio.2004.05.001.

Soliva-Fortuny R.C., Martín-Belloso O. 2003. New advances in extending the shelf-life of fresh-cut fruits: a review. Trends in Food Science and Technology 14: 341-353. DOI: 10.1016/s0924-2244(03)00054-2.

Sangsuwan J., Rattanapanone N., Rachtanapun P. 2008. Effect of chitosan/methyl cellulose film on microbial and quality characteristics of fresh-cut cantaloupe and pineapple. Postharvest Biology and
Technology 49: 403-410. DOI: 10.1016/j.postharvbio.2008.02.014.

Toivonen P.M.A. 2008. Application of 1-methylcyclopropene in fresh-cut/minimal processing systems. HortScience 43(1): 102-105. DOI: 10.21273/hortsci.43.1.102.

Toivonen P.M.A., Brummell D.A. 2008. Biochemical bases of appearance and texture changes in freshcut fruit and vegetables. Postharvest Biology and Technology 48: 1-14. DOI: 10.1016/j.postharvbio.2007.09.004.

Trinchero G.D., Sozzi G.O., Covatta F., Fraschina A.A. 2004. Inhibition of ethylene action by 1 -methylcyclopropene extends postharvest life of 'Bartlett' pears. Postharvest Biology and Technology 32: 193204. DOI: 10.1016/j.postharvbio.2003.11.009.

Vilas-Boas E.V. de B., Kader A.A. 2006. Effect of atmospheric modification, 1-MCP and chemicals on quality of fresh-cut banana. Postharvest Biology and Technology 39: 155-162. DOI: 10.1016/j.postharvbio.2005.09.010.

Villavicencio L., Blankenship S.M., Sanders D.C., Swallow W.H. 1999. Ethylene and carbon dioxide production in detached fruit of selected pepper cultivars. Journal of the American Society for Horticultural Science 124(4): 402-406. DOI: 10.21273/jashs.124.4.402.

Watkins C.B., Nock J.F., Whitaker B.D. 2000. Responses of early, mid and late season apple cultivars to postharvest application of 1-methylcyclopropene (1MCP) under air and controlled atmosphere storage condition. Postharvest Biology and Technology 19: 17-32. DOI: 10.1016/s0925-5214(00)00070-3.

Watkins C.B. 2006. The use of 1-methylcyclopropene (1MCP) on fruits and vegetables. Biotechnology Advances 24: 389-409. DOI: 10.1016/j.biotechadv.2006.01.005.

Watkins C.B. 2008. Overview of 1-methylcyclopropene trials and uses for edible horticultural crops. HortScience 43(1): 86-94. DOI: 10.21273/hortsci.43.1.86.

Weichmann J. 1987. Postharvest Physiology of Vegetables. Marcel Dekker, 597 p. 